New Developments in Sheep Production

Occasional Publication No. 14-British Society of Animal Production 1990

edited by C. F. R. Slade and T. L. J. Lawrence

\title{
CLOVER DEVELOPMENT AND ANIMAL PRODUCTION UNDER CONTINUOUS GRAZING
}

\author{
D. W. HOWARD ${ }^{1}$, M. S. GRIFFITHS ${ }^{2}$ and C. JAMES \\ ${ }^{1}$ Trawsgoed/Pwllpeiran Experimental Husbandry Farm, Trawsgoed, Aberystwyth $S Y 234 H T$ \\ ${ }^{2}$ ADAS/FCS Regional Offices, Trawsgoed, Aberystwyth SY23 $4 H T$
}

\section{INTRODUCTION}

$\mathbf{C}$ urrent and previous investigational work suggests that a rotational grazing pattern increases the proportion of clover in swards grazed by sheep (Newton, Wilde and Betts, 1985). However, on grassland farms where sheep predominate a system of continuous grazing is more commonly adopted (McAdam, 1987; Parsons, Penning, Orr and Jarvis, 1987). A replicated trial was established in March 1987 to evaluate the effect of continuous variable stocking by sheep, incorporating two levels of $\mathrm{N}$ fertilizer, on animal production and the proportion of clover in the sward.

\section{MATERIAL AND METHODS}

The seeds mixture sown and established during May 1986 consisted of $13 \mathrm{~kg}$ perennial ryegrass (cv. Borvi,

Ewe grazing days: March to weaning

1987

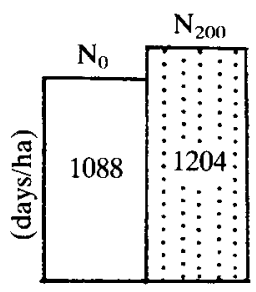

1988

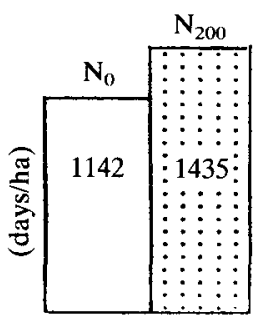

Lamb performance: weaning to 30 September
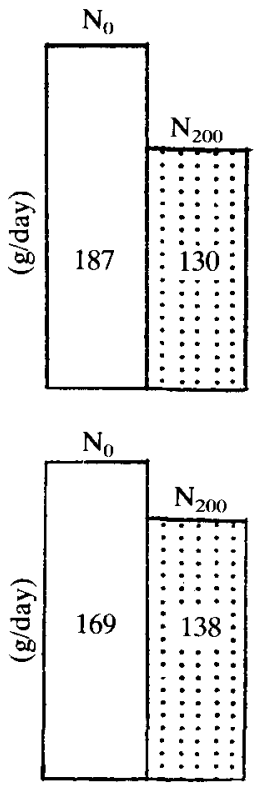

Talbot, Contender), $1 \mathrm{~kg}$ timothy (cv. Goliath) and $1 \mathrm{~kg}$ white clover (cv. Grasslands Huia).

There were two levels of nitrogen: $200 \mathrm{~kg} \mathrm{~N}$ per ha applied in five dressings $\left(\mathrm{N}_{200}\right) ; 0 \mathrm{~kg} \mathrm{~N}$ per ha $\left(\mathrm{N}_{0}\right)$.

Ten mature Welsh Mule ewes and their twin lambs (core animals) were allocated to each of four $0 \cdot 8$-ha plots at the end of March in each year. Sward surface height (5 $( \pm 1) \mathrm{cm}$ ) was maintained on all plots by continuous variable stocking using dry sheep to weaning and lambs between weaning and 30 September. Sward height measurements were taken twice weekly ( 40 recordings per plot). Physical data of the core ewes and lambs was recorded at 14-day intervals. A total of $200 \mathrm{~kg} \mathrm{~N}$ per ha was applied for treatment $\mathrm{N}_{200}$, in five equal dressings in March and at 42-day intervals. Phosphate and potash were applied when necessary to maintain a soil index 2 .
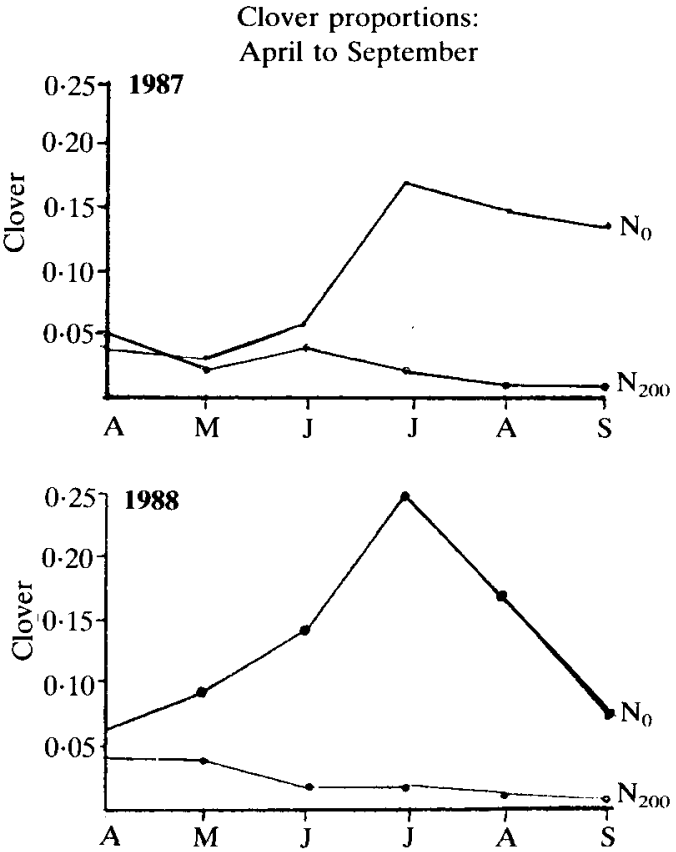

FIG. 1 Summary of results. 
Net herbage accumulation ( $t$ organic matter $(\mathrm{OM})$ per ha) and clover content (kg dry matter (DM) per kg total herbage DM) were recorded every 3 weeks. Lambs were selected for slaughter when they reached a minimum live weight of $38 \mathrm{~kg}$ and a level of finish assessed to produce a carcass of Meat and Livestock Commission (MLC) fat classes 2 and 3. In both years, supplementary feeding was introduced at the end of May when sward height fell below $4 \mathrm{~cm}$. This necessitated supplementing ewes on each treatment in year one (1987) and those on $N_{0}$ in year two (1988). Feeding continued until weaning.

\section{RESULTS}

The results are summarized in Figure 1. The mean sward surface heights for both years between March and weaning were 4.25 (s.e. 0.86 ) cm and 4.95 (s.e. 0.75$) \mathrm{cm}$ for the $\mathrm{N}_{0}$ and $\mathrm{N}_{200}$ swards respectively. Total herbage OM production on $N_{200}$ was proportionately 0.13 greater than on $\mathrm{N}_{0}(6.06 v \cdot 6.85 \mathrm{t}$ OM per ha).

Total lamb live-weight gain ( $\mathrm{kg} / \mathrm{ha}$ ) between March and 30 September was similar for each treatment in 1987 $(847 v .845 \mathrm{~kg} / \mathrm{ha})$. In 1988 however, total production on $\mathrm{N}_{0}$ was proportionately 0.09 greater than on $\mathrm{N}_{200}(1094$ v. $999 \mathrm{~kg} / \mathrm{ha}$ ).

The carcass weights of finished lambs on $\mathrm{N}_{0}$ were significantly heavier in each year $(17.8 v .16 .6 \mathrm{~kg}$ in $1987)$ and $(17.4 v .16 .8$ in 1988$)(P<0.05)$.

\section{CONCLUSIONS}

$\mathrm{N}_{200}$ carried more ewes per ha between stocking and weaning. Lambs on $\mathbf{N}_{0}$ had a significantly greater live-weight gain $(P<0.05)$ between weaning and 30 September, and their carcass weights were significantly greater $(P<0.05)$. The proportion of clover in the total herbage DM peaked in July in each year.

\section{REFERENCES}

McAdam, J. H. 1987. Annual output from grass and grass clover hill swards grazed with ewes. In Efficient Sheep Production from Grass (ed. J. E. Pollott), Occasional Symposium, British Grassland Society, No 21, pp. 195-197.

Newton, J. E., Wilde, R. M. and Betts, J. E. 1985. Lamb production from perennial ryegrass and perennial ryegrass/white clover swards using set stocking or rotational grazing. Research and Development in Agriculture 2: 1-6.

Parsons, T., Penning, P., Orr, R. and Jarvis, S. 1987. Are grass clover swards the answer to nitrogen pollution? Science, Agriculture and the Environment, pp. 10-11. Agricultural and Food Research Council, London. 